\title{
Brazilian Modernism and Cultural Criticism
}

\author{
Valter Sinder ${ }^{1 *}$, Paulo Jorge da Silva Ribeiro ${ }^{2}$ \\ ${ }^{1}$ Department of Social Sciences, Pontifical Catholic University of Rio de Janeiro Rua Marques de São Vicente, 225 - Vila dos Diretórios, \\ casa XVIII Rio de Janeiro 22451-900 Brazil \\ ${ }^{2}$ Department of Political Science, State University of Rio de Janeiro Rua Sao Francisco Xavier, 524 - Rio de Janeiro, Pavilhão Joao \\ Lyra Filho, 2115 F, 20550-013 Brazil
}

Corresponding Author: Valter Sinder, E-mail: vsinder@puc-rio.br

\section{ARTICLE INFO}

Article history

Received: November 04, 2018

Accepted: December 26, 2018

Published: January 31, 2019

Volume: 7 Issue: 1

Conflicts of interest: None

Funding: None

\begin{abstract}
The purpose of this paper is to disclose some issues of Brazilian Modernism (in the 1920's) and to discuss how the leading exponents of this movement attempted to shape a new and authentic way of evaluating the Brazilian national project, showing their views on cultural criticism as a whole. This paper is also an attempt to understand how contemporary criticism re-evaluates this aesthetic and critical project. The late 1970`s and early 1980`s can be seen as fundamental to all the changes in scenarios, images and discourses that took place in Brazil. These changes were not limited to the composition of pragmatic, academic and disciplinary scenarios, but there was an attempt to bring about changes in the face of Brazil. The new agenda of civil society began to be redefined and the relations between public and private worlds were in the spotlight again. The end of the authoritarian military rule was not only a rupture with the current institutional pattern, but it altered deeply the way of thinking about the country.
\end{abstract}

\author{
Keywords: \\ Brazilian Modernism, \\ Brazilian National Project, \\ Cultural Criticism
}

\section{BRAZILIAN MODERNISM}

Without making little of former attempts, dating basically from the turn of the twentieth century, it is possible to notice that the Brazilian modernist movement, originated around the 1920 's, consolidated as the most expressive endeavor to press ahead the review of the romantic mythology and its agenda (as an artistic movement). This agenda was based mainly on its close relation with nationalist feelings. In Brazil, the coincidence between the rise of the Romantic school and political independence, in 1822, only strengthened this relation. Trying to define the contours of the nation, Brazilian Romanticism favored the contemplation of Nature and chose the tropical attributes as a distinctive feature of the American continent. The Indians were elected as the only element capable of creating a bond between our innate tropical disposition and a way of life intended to be seen as truly Brazilian, that is, prior to the Portuguese colonization.

By 1873, Machado de Assis, in an essay called Instinto de nacionalidade (Nationality Instinct), reviewed critically the proposals of the Brazilian nation. Referring to the prose and poetry penned by some of the leading representatives of Brazilian Romanticism, especially José de Alencar, Machado de Assis wrote:
I must add that, at this point, some people are of the opinion, which I deem to be wrong, that the national spirit can only be recognized in those pieces of work that deal with local subjects, a doctrine that, if correct, would limit extremely the assets of our literature [.] A poet does not become national just because he inserts in his verses countless names of the country's flowers or birds species, which may confer at most a vocabulary nationality but nothing else. Local color is something to be valued, but it is necessary that imagination gives it some touches, and that these be natural, not counterfeit. Poems, novels, all literary forms of thought try to clothe themselves in the country's own colors, and one cannot deny that such a concern is a symptom of vitality and future bonus $[\ldots]$ There is no doubt that a literature, especially an incipient one, must feed mainly on the subjects offered by its region; but let us not establish any absolute doctrines that might impoverish it. What should be demanded from a writer, above anything else, is a certain intimate feeling, which makes him a man of his time and of his country, even when he deals with remote subjects in time and space [.] No other writer possessed the Brazilian soul to such a degree, and it was not only because he attended to our national subjects. There is a

Published by Australian International Academic Centre PTY.LTD.

Copyright (c) the author(s). This is an open access article under CC BY license (https://creativecommons.org/licenses/by/4.0/)

http://dx.doi.org/10.7575/aiac.ijclts.v.7n.1p.19 
way of perceiving and discerning, which provides the intimate note of nationality, independent of the external face of things. The most French of the French tragics is Racine, who only made the ancient speak" (Machado de Assis, 1994:30).

In their struggle against the Old Republic of Letters, modernist writers searched for an acuter and more critical understanding of our history. They also advocated a reform of contemporary literary codes, renouncing the photographic realism of naturalists and denouncing eruditism, archaism and the attachment to the European Portuguese grammar. They defended a creative usage of the national lexicon and a "natural" and "neological" language (see Andrade, O., 2017 - Manifesto pau-brasil, 1924 [Brazilwood Manifesto] and Manifesto antropófago, 1928 [Anthropophagic Manifesto]). The modernist movement decoded certain changes in Brazilian society. From the 1920's on, after the landmarks represented by Lasar Segal (in 1913) and Anita Malfati's (in 1917) art exhibitions, there began a process that would become boisterously explicit with São Paulo's Modern Art Week in 1922. A movement devoted basically to "modernizing Brazil" and cultivating its "genuine features". Its mainsprings were therefore "modernization" and "authenticity".

\section{MORE THAN AN AESTHETICAL MOVEMENT}

The guidelines of the 1922 project were summed up later by Mario de Andrade at a conference in 1942: the "stabilization of a national creative conscience" and "the right to aesthetical research and to the universal updating of artistic creation" (Andrade, M.; 1942:45).

As Veloso and Madeira pointed out in their study on the trajectory of Brazilian literature and social thought, in the modernist aesthetical and political revaluation,

The people and the nation came up [...] as mediating categories between the local and the universal. The common people were seen as trustees both of the "national spirit" and of cultural authenticity and originality. In the modernist narratives, it is possible to identify a relation of equality, a virtual synonymy between people and culture. The overlaying of these categories was to impart a particular characteristic to the nationalism elaborated then, which remained full of vigor in every cultural debate up to the 1970's. Culture, understood as civilization, was to express and constitute a universal reason derived, all the same, from singular and creative situations in which the people were protagonists" (Veloso \& Madeira, 1999:98).

This modernist rearrangement of literature and nationality parameters was approached in an ingenious way by Eneida Cunha Leal in her doctorate thesis, Estampas do imaginário (Patterns of the Imaginary) (1993). From a perceptive premise, she chose the scene of the first Mass in Brazil - reported by Pero Vaz de Caminha in a letter, in which the imitative and subservient behavior of the Indians before the Europeans was praised - as a protoscene of the Brazilian historical and cultural identity, a depiction that originated dependence:

Since the last century, since the Romantic deliberation to furnish the country with an identity, that the elements in relief - the components of nationality - are the same depicted in the scene of the first Mass. What varies is the angles of viewing; the values attributed to each of these elements; the willingness to preserve, correct or revert the rules that organize a balanced representation of the meeting between the Western civilization and the New World" (Leal, 1993:5).

Leal argues that those romantic texts more committed to the representation of nationality in a founder context, such as José de Alencar's Iracema, as they contemplate the scene of the first Mass will feel compelled to correct the image of absolute passivity of the Indians, transferring the meeting between them and Europeans from a ritual and religious circumstance to a level of familial conjunction, sanctioned by affection.

The new dramatizations of the original scene did not allow ruptures or radical changes: "the elements of the scene are the same - the activities of the colonist, the Indians' receptivity, and a State project that to be accomplished demanded some kind of interaction, even at a symbolic instituted level, between the two parties" (Leal, 1993:7).

Modernist writers, as they retrieve the scene of the first Mass, try to alter the image fixed by Caminha and restored by romantic nationalism, proposing new values and functions to those elements that blend at the moment of Brazil's discovery:

The modernist version of the first Mass follows a path opposite to that of the romantic construction. It does not suggest substituting the circumstances of the meeting to keep the currency of the imaginary significations that bring them forth. It inverts the romantic process, keeping the ritual aspects of the meeting, but as it transfers to the Indians all the activity, it replaces the disembodied Christian Communion for the actual devouring of bodies. Anthropophagy is suggested as a representation that counteracts the ill-at-ease feeling of colonial life and the colonized attitude" (Leal, 1993:11).

The Modernist movement, however, did not limit itself to alter the role traditionally ascribed to the Indians. The cultural contribution proffered by the Africans, rejected both by the romantics and by a whole reductionist and ethnocentric tradition, which did not exclude Machado de Assis himself and his observations in the above-mentioned Instinto de nacionalidade (1994 [1873]), concerning the void influence of the "Indian element" in "Brazilian civilization", will be rescued by the modernists.

In fact, as José Paulo Paes (1990) suggested, the notion of cultural crossing reached a maximum degree of lucidity with the 1922 modernists, especially after the publication of Manifesto pau-brasil (1924). Two factors were of decisive importance, the essayist reminds us, to urge this "cultured promotion of barbarism". On the one hand, the close proximity to the primitivist vogue predominant in European vanguardist movements, which were discovering African primitive sculptural art and poetry; on the other hand, the solid relation established between the modernists from São Paulo and Blaise Cendrars, whose 1918 Anthologie nègre, consolidated as an exponent of literary neo-primitivism. 
The affiliation to the primitivist fashion took place, however, on premises different from those in Europe. It happened here accordance with Oswald de Andrade's (2017) proposal, put forward in his Manifesto antropófago (1928), of finding out the Brazilian identity through a process of cultural recovery:

Having as its motivation satiety, if not the renunciation of Western civilization, the European vanguards' Primitivism revealed its tendency to avoid what is familiar and to go in search of what is exotic. The Primitivism postulated by the Brazilian modernists in 1922 meant, in opposition, the quest for remote roots, and supposedly more authentic, of their own culture. Hence the regression they proposed with such delight in verse and prose was less to an individual infancy than to a national infancy [...] Resorting to the historical origins of nationality, to the mythical moment that surrounds the meeting between Indians and Europeans, was similar to a purification bath so as to recover that primitive "innocent state" typical of children, which was compared in one of the articles contained in the 1924 Manifesto pau-brasil to a state of grace" (Andrade, O.; 2017:66-67).

The Modernist movement was part of a more complex process that aimed at rethinking Brazil. As Hélgio Trindade points out,

The key year of the period is 1922 . Four symbolic events that contained, in embryo, the mutation of Brazilian society between the two World Wars took place then. The Week of Modern Art in February brought about the aesthetic revolution; a new stage in the political organization of the working classes was delineated, in March, with the foundation of the Communist Brazilian Party; the creation of a Catholic-oriented centre called D. Vital, linked to the magazine $A$ Ordem, foretold a spiritual renewal; and, lastly, the first stage of the Lieutenant's Revolution broke out in July with the rebellion begun in the Copacabana Fortress.

The three elements that had until then formed the tripod on which the political system of the First Republic relied (the large coffee plantations and cattle-raising farms; the primary exportation economy and the control of political power by rural oligarchies), with the transformations that took place from 1920 onwards, changed the Brazilian state foundations at a structural and ideological level, since, as Ferreira Lima points out, 'the intense industrialization that came about at the first postwar period did not have only material but ideological repercussions"" (Trindade, 1974:67).

The understanding of the Brazilian past does not have, therefore, the same connotation as the European invective against the past, with all its rejection to academic traditions, Cartesianism and the century-old weight of countless sedimentary institutions. The Brazilian modernist movement was marked by an interpretation according to which the ideas of historical past and tradition were positively valued, since they represented an open path to present and future renewal (see Veloso \& Madeira, 1994, Madeira, 2002 and Coelho, 2012). As Veloso and Madeira stated, Modernism, more than an aesthetical movement, was also "a way of thinking and acting collectively elaborated, which brought about the rise of consistent and concise aesthetical practices and socio-cultural interpretations that had great repercussions in society as a whole". In short, "Modernism represented a new way of interpreting the common people, the Brazilian nation and culture" (Veloso and Madeira, 1999:94-5).

\section{CONTEMPORARY CRITICISM AND THE REVALUATION OF THE MODERNIST AESTHETIC AND CRITICAL PROJECT}

The modernist legacy was submitted to infinite and divergent revaluations in the 1980's (see Simioni, 2013, Ridenti, 2014). This legacy and, especially, the anthropophagic proposal of assimilating critically the European contribution and transforming it into a new product continued to bring forth new pieces of work and reflections related to the issue of cultural dependence. Among the most representatives, two of them deserve a more detailed examination here.

In his Nacional por subtração (National by Subtracting), Roberto Schwartz (1987) investigates the strategies adopted by Brazilian intellectuals since the nineteenth-century to overcome the "uneasiness" caused by the frequent realization of the "false, non-authentic, mimicked character of our cultural life" (Schwartz, 1987:29). As he pores over the Pau-brasil and Anthropophagic manifestoes, Schwartz sees a lot of "naivety" and "jingoism" in their "extraordinary proposals", which he labels as "a triumphant interpretation of our backwardness". Our "maladjustment" was dealt with in an unusual "optimistic" way, as an "evidence of national innocence and of the possibility of an alternative historical course, that is, non-bourgeois" (Schwartz, 1987:37).

According to Schwartz, the equivocal assumptions of the "Oswaldian devouring" were made explicit as they were resumed in the 1970's. According to him, these assumptions served then as a support for the uncommitted reception given to every product of the foreign cultural industry.

Its guiltless swallowing can exemplify an evolution of this kind. What meant freedom in relation to Catholicism, to bourgeois values and fascination with Europe seems today, in the 1980 's, a clumsy and blunt alibi for dealing non-critically with the ambiguities of mass culture, which demand lucidity" (Schwartz, 1987:38).

Silviano Santiago's interpretation of Oswald takes place, in turn, at a totally different level, which is clearly stated from the beginning by the essay's title: Apesar de dependente, universal (Although Dependent, Universal) (Santiago, 1982). In the author's view, the modernist notions of cultural anthropophagy, "brilliantly invented by Oswald de Andrade", of memory betrayal, formulated by Mário de Andrade in his studies on music, and of radical cut, propagated by some vanguardist movements such as the concretists, work as effective antidotes against colonizing and ethnocentric hierarchical tendencies:

In the three cases, there is no presence that dependence simply does not exist; on the contrary, its inevitability is emphasized. The debt to the dominant cultures is not denied; on the contrary, its coercive power is highlighted. 
There is no contentment with a glorious view of natives and blacks, but a search for inserting them into universal totality. At the same time, the possible originality of the created product is not wasted in the limbo of ethnocentric lucubration. The hierarchical classification according to the criteria of "backwardness" and "originality" falls suddenly apart, for these values are subverted. This subversion is not a senseless game of nationalist character, like in the 1930's Integralism, but the realization that, in spite of a culturally dependent production, it is possible to go beyond imitations and mere ethnocentric encyclopedic syntheses, contributing something original" (Santiago, 1982:22).

To operate this subversion, Santiago tells us, it is necessary to question initially the categories of source and influence. In a tactical and deconstructive process of comparative literature, in which the refutation of erudition, the rupture of chronology and the search for originality intermingle creating a paradoxical critical supplement,

the decolonized text of the dominated culture turns out to be richer (not from the viewpoint of a strict internal economy of the work), as it contains in itself both a representation of the dominant text and an answer to this representation at a fabular level. This answer is transformed into a regular standard to rate cultural universality as effectively as those already known and listed" (Santiago, 1982:23).

In Estampas do imaginário (1993), Eneida Cunha Leal points out with propriety that at the core of the discord between Schwartz and Santiago lies the philosophical substrate on which these two authors rely. For Schwartz, Marxist ideology, in which "the question of copy, of uneasiness and of cultural dependency are functions pertaining to a deeper and more complex system of socio-economic domination" (Leal, 1993:15); and for Santiago, the contemporary French thinking of the decolonization philosophers, such as Foucault, Derrida and Deleuze, with their refusal to the concept of origin and to any totalizing orientation.

"The Oswaldian anthropophagic scene, retrieved by this tendency of contemporary thinking" that refuses the search for the origins and any totalizing orientation, reverts to - in the Nietzschian sense - the scene of the first Mass, just as fixed by Caminha and restored by romantic nationalism (Leal, 1993:17). An operation, therefore, that does not aim at the mere exchange of signals or at an inversion of values of historical and imaginary meanings as regards cultural dependency, but at turning it inside out, displaying its motivations and hierarchies, and refusing them. It is known that such a proceeding does not have the power to alter the colonial event and correct the past in retroactive fashion.

Fredric Jameson (1995), in an analysis of post-modern neo-aestheticism, describes this movement in terms of "a growing abstraction" and "an increasing removal from the concrete national context". He argues that, unlike the First World artists, who are supposed to be in a more comfortable position as regards avoiding any reflections on national identity, those from the Third World, owing to their experience of "national poverty", "social crisis", "aggression" and "oppression", are "condemned to self-awareness and to a full knowledge of their own situation" (Jameson, 1995:140).
Hence the currency of a "forced contextualization" and a "national allegory". The latter is defined by Jameson as the way through which a work of art refers, sometimes instinctively or unconsciously, to its own collective situation" (Jameson, 1995:14). He points out, however, that the notion of national allegory to which he refers, in a positive way as could only be expected from a Marxist theoretician, is not a nostalgic repetition of the old craving for an organic community, but the constitution of a new scenario based on the former one.

The late 1970's and the early 1980's can be seen as fundamental to all the changes in scenarios, images and discourses that took place in Brazil. Because these changes were not limited to the composition of pragmatic, academic and disciplinary scenarios, but because there was an attempt to bring about changes in the face of Brazil. The new agenda of civil society began to be redefined and the relations between public and private worlds were in the spotlight again. The end of the authoritarian military rule was not only a rupture with the current institutional pattern, but it altered deeply the way of thinking about the country.

These changes started being felt not only in the daily practices of a given political militancy and life, but also in the loss of the Brazilian aura. The very ways of acquiring intelligibility in relation to the country, both as an urban space to live in and as a cognitive locus, began to change at that period. Added to these transformations, cultural discourses on Brazil and its Brasility, at every level, started to acquire a new face.

It becomes clear here that the discourses voiced within this new geography of ideas are of the utmost importance to the self-recognition of Brazilian society. The search for some sort of identity was to be also acquired by means of new discursive models, much more diversified than the former ones. As Carlos Alberto Messeder Pereira pointed out precisely,

Since the early 1970 's, we are experiencing the explicit crisis of the "modern" paradigm, delineated around the 1920's and 1930's, which handed us down a profile of Brazil that could guide us with great legitimacy along almost 50 years. This is the deflection 1968 is all about, from a cultural viewpoint. Yet it is along the 1980 's that we experienced more radically the beginnings of the modernity "conquest" in Brazil. Both at the level of the subjects originated by cultural production and of the products themselves, or even at the level of theoretical formulations. The labels through which one tries to identify this moment are varied; some talk about 'modernity crises, 'post-modernity', 'utopia failure' and so on. In this sense, revaluing critically this 'cultural/ epistemological volte-face' seems fundamental in my opinion" (Pereira, 1993:10-1).

This modernity crisis, utopia failure, also characterized by a lack of trust in the great paradigms that gave credibility to the rules of science formerly, made possible many revaluations, deconstructions and reinterpretations. Two tendencies, already present in the 1980 's, came up as privileged varieties in the nation's narrativity: the historical novel and the urban novel (understood as metafiction). Since then, we had the opportunity to watch a debate that blurred the rigid boundaries many supposed to separate the narrative 
forms characteristic of the human and social sciences from a typically literary narrative. Brazil is not seen as a historic and geographic monobloc anymore, ready to be artistically and conceptually explored, as it became the object of a new questioning, which demanded new analytical categories such as what makes brazil, Brazil? This movement has made possible to redefine the field of Brazilian literature and social thought, pointing towards changes in the way new (national?) identities are being formed: they are no longer based on the quest for origins and on closed and totalizing structures, but on a plural and diversified way.

\section{REFERENCES}

Alencar, José de. (2011). Iracema. Porto Alegre, LPM.

Andrade, Mario de. (1942). O Movimento Modernista: conferencia lida no salão de conferencias da biblioteca do Ministério das Relacoes Exteriores do Brasil, no dia 30 de abril de 1942. Rio de Janeiro, Casa do estudante do Brasil.

Andrade, Oswald. (2017). Manifesto Antropofago e outros textos (org. J. Schwartz e G. Andrade). Sao Paulo, Penguin-Companhia das Letras. (Manifesto pau-brasil, 1924 and Manifesto antropófago, 1928).

Cendrars, Blaise. (2002). Anthologie nègre. Paris, Le Livre de Poche, (1918).

Coelho, Fred (2012). A semana sem fim - Celebrações e memória da semana de arte moderna de 1922. Rio de Janeiro, Casa da Palavra.

Jameson, Fredric. (1995). Pós-Modernismo. A lógica cultural do capitalismo tardio. Tradução de Elisa Cevasco. São Paulo, Ed. Atica (1991).
Leal, Eneida Cunha. (1993). Estampas do imaginário - tese de doutorado. Rio de Janeiro, PUC-Rio, Departamento de Letras.

Machado de Assis, Joaquim Maria. (1994). Instinto de nacionalidade (1873). In Obra Completa de Machado de Assis. Rio de Janeiro, Nova Aguillar, Vol III. P. 28-34

Madeira, Angelica. (2001). Descobertas do Brasil. Brasilia, Editora da UNB.

Paes, Jose Paulo. (1990). A Aventura Literaria. São Paulo, Companhia das Letras.

Pereira, Carlos Alberto Messeder. (1993). Em busca do Brasil contemporáneo. Brasilia, Editora da UNB.

Ridenti, Marcelo. (2014). Em busca do povo brasileiro: artistas de Revolução, do CPC à Era da TV. São Paulo. Unesp, $2^{a}$ edição revista e ampliada.

Santiago, Silviano. (1982). ^Apesar de dependente, univer-

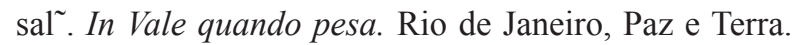
P. 13-24

Simioni, Ana Paula Cavalcanti. (2013). Modernismo brasileiro - entre a consagração e a contestação. Perspective, 2 - 2013, mis en ligne le 19 ferver 2016, consulte le 05 janvier 2019. URL http://journals.openedition.org/perspective/5539; DOI: 10.4000/perspective.5539

Schwartz, Roberto. (1987). Nacional por subtraçãõ. Que horas são? São Paulo, Companhia da Letras.

Trindade, Helgio. (1974). Integralismo - o Fascismo Brasileiro na Decada de 30. São Paulo, Difel, 1974.

Veloso, Mariza \& Madeira, Angelica. (1999). Leituras Brasileiras - Itinerários no pensamento social e na literatura. Rio de Janeiro, Paz e Terra. 